\title{
A Study on the Economic Analysis of the Turkish Black Sea Purse Seiners
}

\begin{abstract}
Tanju MUTLU $^{1}$ A. Cemal DİNÇER ${ }^{2 *}$
${ }^{1}$ Recep Tayyip Erdogan University, Vocational School of Technical Sciences, Department of Fisheries, 53100 Rize, Turkey. ${ }^{2}$ Karadeniz Technical University, Department of Naval Architecture and Marine Machines Engineering, Surmene Faculty of Marine Sciences, 61530, Trabzon, Turkey.
\end{abstract}

\section{Technical Specifications of Fishing Fleet in Giresun Province}

\begin{abstract}
The purpose of this study is to assess the economic performance of the Turkish purse seine operated in the Black Sea. Five commercial fishing vessels of different lengths and engine powers have been chosen as samples to represent the fishing pattern carried out in the region. The catch data used has been obtained from the two successive fishing periods of 2009-2010 and 2010-2011. Net present value (NPV) and internal rate of return (IRR) methods were used as economic evaluation criteria. According to results of economic analysis of sample fishing vessels, the fuel has been found the greatest outcome component of the net cash flows. It was seen that all sample seiners closed the both fishing seasons with profits. The results of analysis also indicated that the engine powers and the gross tonnages (GT) of the seiners have the optimum values of $3000 \mathrm{HP}$ and $250 \mathrm{GT}$, respectively. It was estimated that an ordinary purse seiner is capable of catching 3080 tonnes of anchovy, averagely, per year. This amount is strikingly more than twice of what was shown in the official fishery statistics.
\end{abstract}

Keywords: Fishing vessels, Turkish purse seine, Black Sea, Economic analysis

\section{Türk Karadeniz Gırgır Gemilerinin Ekonomik Analizinin Değerlendirilmesi}

Öz: Bu çalışmanın amacı Karadeniz'de avlanan Türk gırgır gemilerinin ekonomik performansı değerlendirmektir. Bölgede devam eden avlanma şeklinin temsil etmesi amacıyla farkl uzunluklarda ve motor gücünde 5 farkl ticari av gemisi örnek olarak seçilmiştir. Kullanılan avlanma verisi 2010-2011 av sezonunda elde edilmiştir. Net şimdiki değer (NŞD) ve iç getiri oranı (IGO) metotları ekonomik değerlendirme kriteri olarak kullanılmıştır. Örnek balıkçı gemilerinin ekonomik analiz sonuçlarına göre net nakit akışının en önemli çıktı bileşenin yakıt olduğu bulunmuştur. Araştırmada kullanılan gemilerin iki sezonu da karla kapattı̆̆ tespit edilmiştir. Ayrıca analiz sonuçlarına göre gemilerin motor güçlerinin ve grosstonajının (GT) sırasıyla 3000 HP ve 250 GT optimum değerlerde olduğu belirlenmiştir. Bir girgır gemisinin ortalama 3080 ton/yıl hamsi avlayabileceği tahmin edilmiştir. Bu değer resmi balıkçılık istatistiklerine göre iki kat fazla olduğu belirlenmiştir.

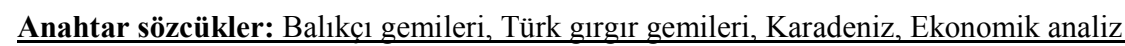

\section{INTRODUCTION}

Anchovy is the most commercially important species of the Black Sea and Turkey, since the Black Sea alone provides approximately $73 \%$ of the total Turkish catch. It is available in large quantities (102595 tonnes) and amounts 39\% of the total marine product (TUIK, 2016). The fluctuations that occur in the level of anchovy catches therefore affect the country's fishing in general. According to the official statistics the yearly anchovy catches vary between 100-400 thousand tonnes (TUIK, 2016). Due to the relatively short fishing period, major part of anchovy catch is used for fish meal and oil industry. However, becoming more commonplace of cold conservation systems has enabled the raise of human consumption (Zengin, 2000).

The purse seining is the preferred technique to capture anchovy. It uses a large seine (purse seine) designed to be set by two boats (main vessel and skiff) around a school of fish and so formed that after the ends have been brought together the bottom can be closed. The fish school is found by fish finding equipment. This fishing method is designed to capture pelagic school, amounting 30 to 40 percent of the total world catch and 80 to 90 percent of the total Turkish catch (Hoşsucu, 2009). This method is accomplished by a main vessel, an auxiliary vessel or 
carriage vessel and a skiff boat (Çelikkale and Ulupınar, 1995). There are 14491 fishing boats in Turkey, 426 of which is purse seiner, 718 of which is trawler, 106 of which is carrier and 13241 of which is the small scale fishing boat. The majority of purse seiners are operated in the Black Sea and the Marmara Sea (TUIK, 2016). The reason of this high vessel concentration in these seas is due to intensive anchovy fishing (Dinçer, 1996). The purse seining is the most labour required method of fishing. The number of crew can be at least 10 to 15 in small vessels and as high as 30 to 40 in bigger vessels (Çelikkale et all, 1999). Recent trends in the increase of number of vessels and sizes together with the irresponsible fishing have caused overfishing (Çelikkale et all., 1999).

\section{MATERIAL and METHOD}

This study is based on the data obtained from five commercial fishing vessels that were operated in the Black Sea for the fishing seasons of 2009-2010 and 2010-2011. The sample vessels were over 20 meters in size and had various engine powers from 400 to 4300 . The data collection process includes the filling in the data sheets by the master fishermen as well as accompanying the fishing operations in the area. The data sheets cover the information necessary for the economic analysis such as fishing area, catch type and amount, and the whole components of income and outcome which are related to operations. Several face to face interviews to fishermen have also been taken place. Oral information provided by fishermen was compared to the accounting records of the companies to validate the accuracy of the data.
The sample vessels were coded as A, B, C, D and E instead of using their real names. Total yearly operating costs for the vessels were broken down into two components as fixed costs and variable costs. The fixed costs include provisions, maintenance and rental cost of carrier vessel. The variable costs include fuel, oil, crew salary, ice and miscellaneous. Vessels' earnings were computed on the basis of fish sales values obtained from the accounting records of the companies. The investment costs of the vessels were considered to be comprise of vessel production cost, machinery cost, fishing gear and equipment cost. The estimation of vessel production cost is based on the information obtained by vessel owners and the ship yards in which they were built. The cost values were updated to the present by means of depreciation rates.

The specifications of five sample purse seiners were presented in Table 1 . The vessel $\mathrm{A}$ is the largest one among them in terms of size, tonnage and engine powers. She has three main engines of 2x1050 plus $2200 \mathrm{HP}$ and has the highest number of fishing days of 125 and 135 for two consecutive fishing seasons. The vessel D has the lowest power of $400 \mathrm{HP}$ with single engine and the lowest gross tonnage of 49 GT. The vessel A and the vessel B have generally greater fishing days in relation to the others since they were operated in both two countries of Turkey and Georgia. The number of crews varies 20 to 30 depending on the size of vessel and gear.

Table 1. The specifications of the sampled vessels.

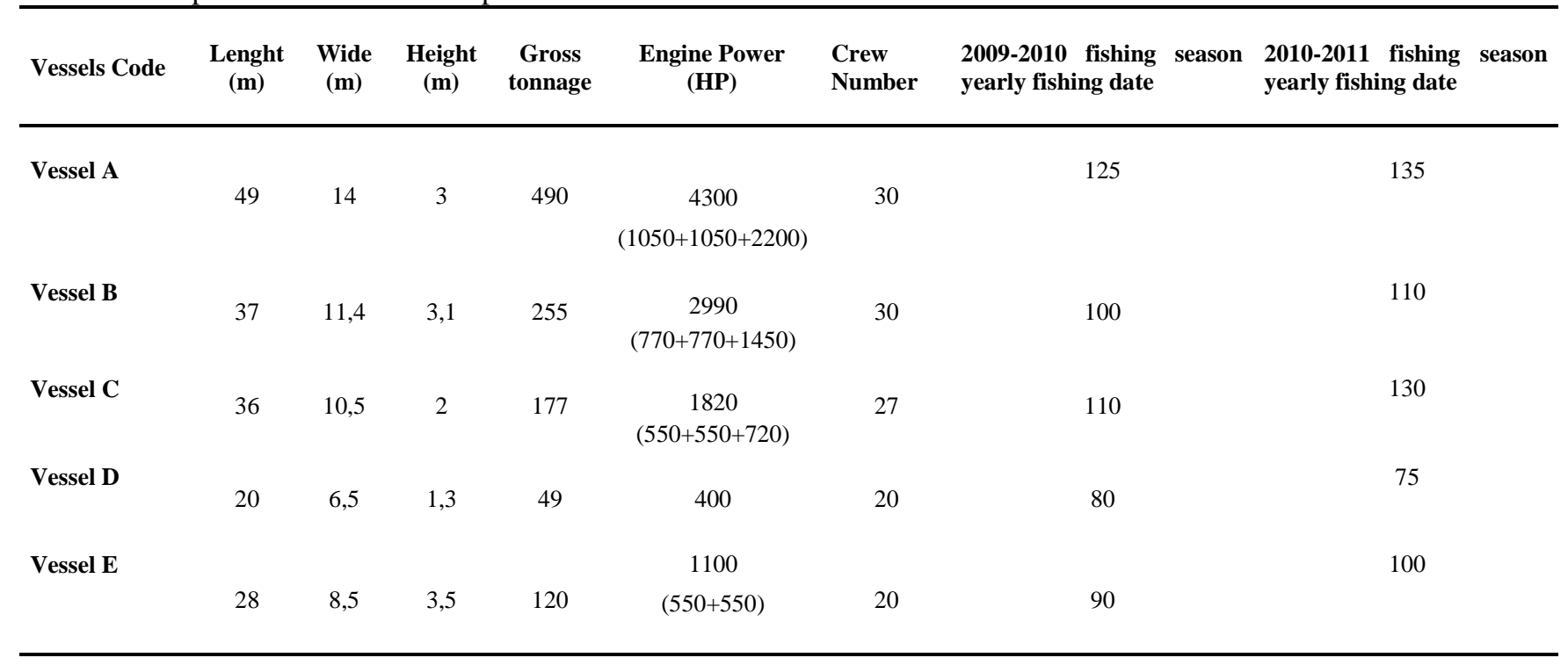

In order to decide whether which investment should be undertaken or whether which particular investment should be preferred to another the net present value (NPV) and the internal rate of return methods (IRR) were used as a measure of evaluation. 
The net present value method (also known as the discounted cash flow method), which is the capital budgeting technique, takes into account the time value of money and uses the net present value of the investment project as a system for accepting or rejecting an investment proposed for the projects. The net present value is the difference between the present of cash inflows and the present value of cash outflows. Can be positive, zero, or negative. It is said that if the current value of the cash inflows is greater than the present value of the cash outflows, the net present value is positive and the investment proposal is acceptable. If the present value of the cash flow is equal to the present value of the cash outflow, it is considered that the net present value is zero and the investment proposal is acceptable. If cash inflows are less than the present value of today's cash outflow, it is stated that the net present value is negative and the investment proposal is rejected. (Fyson, 1985; Lucey, 1985). The general formula for the net present value is as follows:

$$
N P V=\sum_{n=0}^{N} \frac{N C F}{(1+i)^{n}}
$$

Where,

$\mathrm{NPV}=$ net present value, $\mathrm{NNA}=$ net cash flow, $\mathrm{n}=$ years $(1,2,3, \ldots), \mathrm{N}=$ project economic life and $\mathrm{i}=$ discount rate.

The internal rate of return (IRR) is a discount rate (i) that equalizes the net present value (NPV) of all cash flows from a specific project to zero (i) and the IRR calculations are based on the same form as the NPV does. The IRR can not be calculated analytically. Instead, it can be calculated by trial-and-error method from the following formula. It must also be calculated using the software programmed to calculate the IRR. (Fyson, 1985; Lucey, 1985).

$$
\sum_{n=0}^{N} \frac{C O}{(1+i)^{n}}=\sum_{n=0}^{N} \frac{C I}{(1+i)^{n}}
$$

Where,

$\mathrm{CO}=$ cash outflow, $\mathrm{CI}=$ cash inflow, $\mathrm{n}=$ years $(1,2,3, \ldots)$, $\mathrm{N}=$ project economic life and $\mathrm{i}=$ discount rate.

The variation of net present values (NPV) in relation to the engine sizes were presented in Figure 1. As can be seen from this figure, all vessels have a positive NPV values meaning that all investment projects are profitable. There is an optimum value of NPV at about 3000 HP. The variation of internal rate of return values (IRR) in relation to the engine sizes were presented in Figure 2. As can be seen from this figure, the vessel $B$ has the highest IRR value and the vessel A has the lowest IRR value despite of having the highest engine power.
The variations of net present values (NPV) in relation to the gross tonnages (GT) were presented in Figure 3. As can be seen from this figure, all vessels have a positive NPV values meaning that all investment projects are profitable. There is an optimum value of NPV at about 300 GT. The variation of internal rate of return values (IRR) in relation to the gross tonnages were presented in Figure 4. As can be seen from this figure, the vessel B has the highest IRR value and the vessel D has the lowest IRR value.

The variations of the ratios of the net cash flows to the gross tonnage (NCF/GT) in relation to the gross tonnage were presented in Figure 5. As can be seen from this figure, the vessel $\mathrm{D}$ has the highest ratio and the vessel $\mathrm{A}$ has the lowest ratio value.

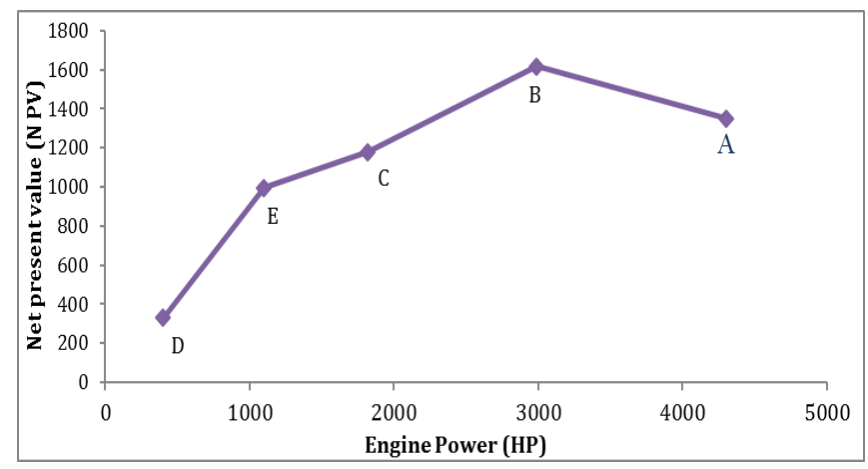

Figure 1. The engine power- net present value (NPV) of the sampled vessels.

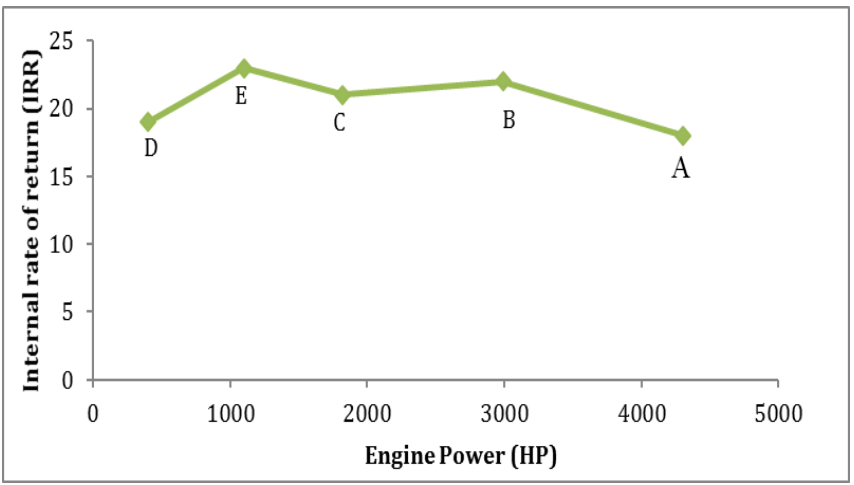

Figure 2. The engine power (HP) - internal rate of return (IRR) of the sampled vessels.

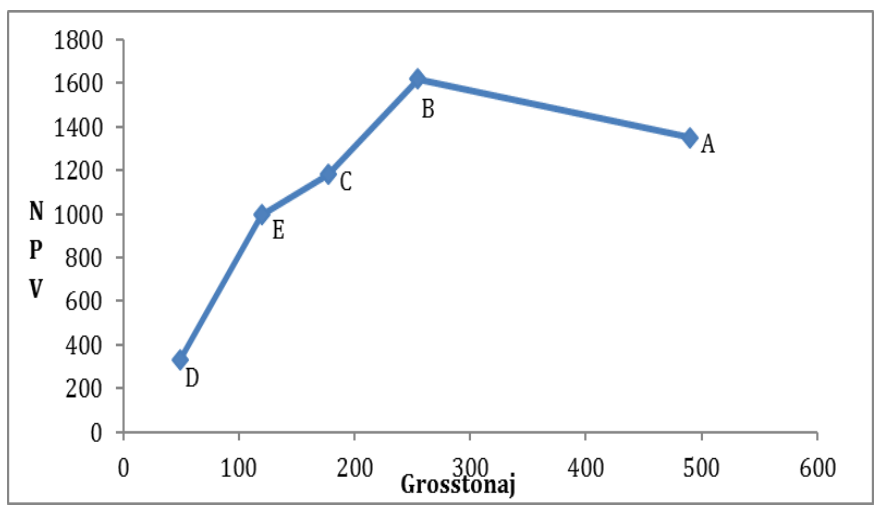

Figure 3. The gross tonnage - net present value of the sampled vessels 


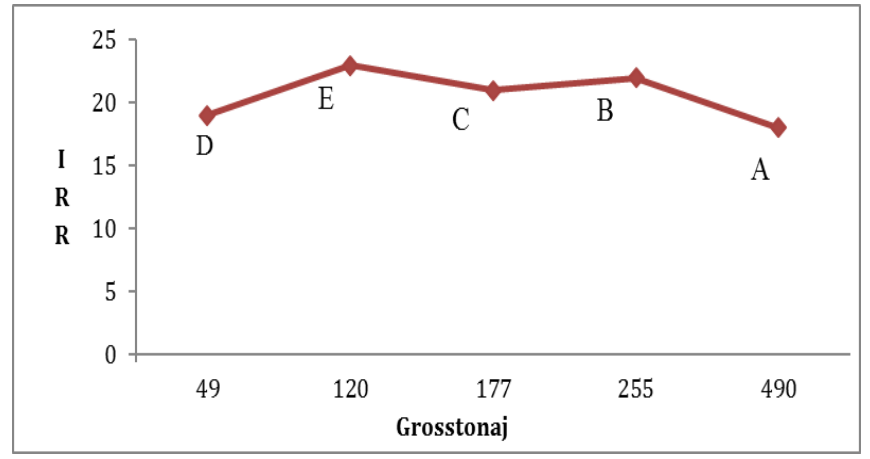

Figure 4. The gross tonnage-internal rate of return (IRR) of the sampled vessels.

\section{DISCUSSION}

The running costs were considered to be the sum of annual fixed costs and annual variable costs. It has been seen that the annual fixed costs has varied with the size of vessels. Although the maintenance component of fixed cost generally varies in relation to the vessel size, but in some cases, it can also be affected by the failure or break down of the some functional components and accidental occurrences. The cash outflows of vessels A and C appear to be higher in comparison with the others. The reason for that these vessels fished in two countries waters (Turkey and Georgia) for both fishing seasons. For the season of 2009-2010 the major component of fixed cost was the rental fees of carrier vessels.

The major parts of the variable costs were fuel for the vessels of A, B and C, and the crew salaries for the vessels of $\mathrm{D}$ and $\mathrm{E}$. The average fuel costs for two seasons and for the all vessels were computed to be $23.5 \%$ of the total outflows. Among all vessels the highest fuel consumption rate was for the vessel $\mathrm{B}$. The reason for that this vessel has the longest fish searching time and the higher number of fishing operation. It has been found that the purse seine net is the most valuable part of a fully equipped seiner vessel, averagely amounting for $31 \%$ of the total vessel investment cost. The number of crew engaged in the vessels depends on the size of vessel and the net used.

The catch generally is composed of small pelagic as anchovy, horse mackerel and bonito. Anchovy is the major part of the catch and is consumed mainly as human food and the smaller sizes as fish meal and oil. Among these species the anchovy is the cheapest one but available in large quantities and thus amounting the highest revenues. The bonito is the most commercially valuable fish but available in fewer quantities and subjected to more valuable consumer prices. The horse mackerel is a bit more expensive than anchovy and is the second in terms of availability.

When considering the NPV variation by the engine power the vessel $\mathrm{B}$ appears to be the most profitable investment and followed by the vessel $\mathrm{A}$ and the others are considerable less profitable (Figure 1). However, all vessels

are profitable. According to IRR method the most profitable vessel is the $\mathrm{E}$ and is followed by the vessel $\mathrm{B}$ (Figure 2). In general it can be said that for the engine power there is an optimum value around 3000 HP. That means there is no point in increasing the power beyond this value from economy view point.

When considering the NPV variation by the tonnage (GT) the profitabilities of the vessels are of same order as engine power. The vessel B again appears to be the most profitable investment and followed by the vessel $\mathrm{A}$ and the others are considerable less profitable (Figure 3). The GT value is an important measure of vessel size and represents the volumetric capacity in general. From this figure it can clearly be seen that there is an optimum value of NPV around $250 \mathrm{GT}$.

Total amount of anchovy caught by 5 sample vessels in 2009-2010 and 2010-2011 fishing seasons were 14360 and 16440 tonnes, respectively. From this, the average catches per unit of vessel are computed to be 2872 and 3288 tonnes, respectively. Therefore, the overall annual mean for both fishing seasons is calculated to be 3080 tonnes of catch per vessel. Taking into account the total number of Turkish purse seiner of 150 we arrive total anchovy catch of Turkey of 462000 tonnes. This figure is more than twice of that is in the official fishery statistics. This may be interpreted that the official fishery statistics are not properly recorded and their reliabilities are arguable

\section{Acknowledgements}

This work supported by Research Fund of Karadeniz Technical University (Project No: 2010.117.001.1).

\section{REFERENCES}

Çelikkale, M.S., Ulupınar, M., (1995). Büyük gırgır takımlarının ekonomik analizi, Su Ürünleri Dergisi, 12, 1-2, $79 \mathrm{~s}$.

Çelikkale, M.S., Düzgüneş, E. ve Okumuş, İ., (1999). Türkiye su ürünleri sektörü ve Avrupa Birliği ile entegrasyonu. İstanbul Ticaret Odası Yayın No: 1992-2, İstanbul, 32-34, $55 \mathrm{~s}$.

Dinçer, A.C. (1996). Hamsi avcılığında kullanılan Karadeniz tipi balıkçı gemilerinin simülasyon dizaynı ve ekonomik analizi, Doktora Tezi, K.T.Ü., Fen Bilimleri Enstitüsü, Trabzon. 
Erdoğan, N. (2006). Türk Balıkçılık Filosu ve Balıkçılık Yönetimi Açısından Değerlendirilmesi, Doktora Tezi, Ege Üniversitesi, Fen Bilimleri Enstitüsü, İzmir.

Fyson, J. (1985). Design of small Fishing Vessels, FAO Fishing News Ltd. Farnham, England, $35 \mathrm{~s}$.

Hoşsucu, H. (2009). Balıkçılık I avlanma araçları ve teknolojisi. Ege Üniversitesi Basımevi, Ege Üniversitesi Su Ürünleri Fakültesi Yayınları, No: 55, İzmir, $169 \mathrm{~s}$.

Lucey, T. (1985). Quantitative Techniques. An Instructional Manual, 2nd Edition, D.P. Publications Ltd., Eastleigh, Hampshire.

Yücel, Ş. (2006). Orta Karadeniz Bölgesi balıkçılığı ve balıkçılığın sosyo-ekonomik durumu, Ege Üniversitesi Su Ürünleri Dergisi, 23(1-3), 529 s.
Zengin, M. (2000). Doğu Karadeniz'de Hamsi'ye dayalı olarak faaliyet gösteren balık unu-yağı fabrikalarında son on y1lda (1990-2000) meydana gelen gelişmeler. Su Ürünleri Sempozyumu, Sinop, 327-341 s.

Received date: 14.03 .2018

Accepted date: 10.05 .2018

\section{*Corresponding author's:}

Prof. Dr. A. Cemal DINCÇER

Karadeniz Technical University, Department of Naval Architecture and Marine Machines Engineering, Surmene Faculty of Marine Sciences, 61530, Trabzon, Turkey.

E-mail: cdincer@ktu.edu.tr) 